\title{
Development of Analytical Method for Quantification of Trace Metallic Impurities in U-Mo Alloy Employing Time-of-Flight-based ICP-MS
}

\author{
B.K. Nagara,b, M.K. Saxena ${ }^{\mathrm{b}}$, and B.S. Tomar ${ }^{\mathrm{a}, \mathrm{b}, *}$ \\ a Homi Bhabha National Institute (HBNI), Anushaktinagar, Mumbai-400094, India \\ ${ }^{b}$ Radioanalytical Chemistry Division, Bhabha Atomic Research Centre, Mumbai-400085, India
}

\section{INTRODUCTION}

As part of non-proliferation of nuclear materials, various nuclear reactors using very high uranium (U) enrichment are being switched over to fuels of lower $\mathrm{U}$ enrichment. However, the resultant loss of power is compensated by raising the fuel densities. Several types of fuels such as intermetallic and alloys are being studied which can provide high U density (1-3). Lowenriched uranium alloys with 6 to $12 \mathrm{wt}$. \% of Mo are under consideration in the Indian nuclear program since very high density fuels alloying Mo with uranium stabilize uranium in the Y-phase, which is preferred owing to the advantages related to better accommodation of fission products and swelling behavior. Reported studies show that maximum $\gamma$-phase stabilization can be achieved with $10 \%$ Mo in U-Mo alloy (4-6).

There are a number of factors which need to be considered for realizing the performance design of the nuclear fuel inside the reactor. The fabricated fuels before their final use should be certified for the presence of various impurities. Owing to the deleterious effects associated with these trace impurities, their maximum limit is specified (7-10). Boron, cadmium, and some rare earth elements ( $\mathrm{Sm}, \mathrm{Eu}$, Gd, Dy) have very large neutron absorption cross-sections and can affect the neutron economy. Low melting elements such as zinc, if present, may cause liquid metal

*Corresponding author.

E-mail: bstomar@barc.gov.in

Tel: +91-22-25595006

\section{ABSTRACT}

Low-enriched uranium-molybdenum (U-Mo) alloy is being evaluated for its suitability as a fuel for research reactors. As a part of chemical quality control (CQC), a simple and effective method for the determination of trace and ultratrace elements in U-Mo alloy has been developed. In the present study an anion exchange method was used for separating the bulk U and Mo matrix simultaneously to enable trace element determination. Subsequently, the effect of the bulk matrix separation on the recovery for trace elements was studied. It was found that Al, As, Ce, Cr, Co, $\mathrm{Cs}, \mathrm{Cu}, \mathrm{Dy}, \mathrm{Eu}, \mathrm{Er}, \mathrm{Gd}, \mathrm{Hf}, \mathrm{Ho}$, $\mathrm{La}, \mathrm{Lu}, \mathrm{Mg}, \mathrm{Mn}, \mathrm{Nd}, \mathrm{Ni}, \mathrm{Pb}, \mathrm{Pr}$, $\mathrm{Rb}, \mathrm{Rh}, \mathrm{Sc}, \mathrm{Sm}, \mathrm{Sr}, \mathrm{Tb}, \mathrm{Tm}, \mathrm{V}, \mathrm{W}$, $\mathrm{Y}, \mathrm{Yb}$, and $\mathrm{Zr}$ have recoveries between $75-100 \%$. The instrument detection limit (IDL) and the method detection limit (MDL) for the 33 analytes were found to be in the range of 5-200 ng $\mathrm{L}^{-1}$ and $1-15 \mu \mathrm{g} \mathrm{kg}^{-1}$, respectively. Real samples were analyzed successfully with the \%RSD between $5-15 \%(1 \sigma)$.

embrittlement (LME) alter the fuel structure which in turn may lead to failure. On the other hand, refractory elements, such as tungsten, may cause "creep resistance" resulting in cladding damage. Elements, which get incorporated in nuclear fuel either from the precursors or during various fuel fabrication steps, need to be quantified precisely and accurately.

Various methods are available for the determination of trace metallic elements in nuclear materials, i.e., inductively coupled plasma mass spectrometry (ICP-MS) (11-14), inductively coupled plasma atomic emission spectrometry (ICP-AES) (15), and ion chromatography (IC) (16), etc. Among all these techniques, ICP-MS is the most versatile multielemental technique with rapid analysis, high sample throughput, wide linear calibration range, low detection limit, and fewer spectroscopic interferences (17-19).

The mass spectrometric technique cannot be used for samples having high matrix concentration. For ICP-MS analysis, it is recommended to analyze solutions with total dissolved solid content $\leq 0.2 \%$. Such samples require a pre-analysis matrix separation procedure which can reduce or eliminate the matrix. The matrix under study contains $\mathrm{U}$ and Mo. Several studies are reported where solvent extraction is used to separate the U matrix (20-26). Similarly, organic extractants like Cyanex-923 and oxime (8-diethyl-7-hydroxydodecane-6oxime) have been used for separating Mo (27-29). Though the solvent extraction methods have been used successfully, they are laborious, time-consuming, and involve large volumes of organic solvents, especially when the method is employed on a routine basis. It is also possible to separate the Mo matrix by precipitation (30), uranium by hydrolytic precipitation, or by formation of yellow cake $(31,32)$. However, for the matrix under study, the use of two different methods for $\mathrm{U}$ and Mo will be cumbersome. It is also important to consider that the separation method should not affect the recovery of the analytes. 
Various reports suggest that $\mathrm{U}$ and Mo can form chloride complexes which are anionic in nature $(33,34)$. The anionic complexes formed with chloride have been utilized for separation of $\mathrm{U}(35,36)$ and Mo $(37,38)$ separately. It is possible to have a medium where both U and Mo form anionic chloride complexes which can be separated simultaneously from the matrix. In the current work, anion exchange separation is investigated for the simultaneous separation of $\mathrm{U}$ and Mo from the various analytes. Recovery studies are carried out to understand the loss of analytes.

\section{EXPERIMENTAL}

\section{Instrumentation}

An inductively coupled plasma orthogonal acceleration Time of Flight mass spectrometer (ICP-OaTOF-MS), Model Optimass 8000R (GBC, Australia) was employed for the quantification of trace and ultratrace elements in U-Mo alloy. Details of the instrumental and operating parameters are given in Table I.

\section{Chemicals and Solutions}

Bio-Rad $\mathrm{AG}^{\circledR} 1 \mathrm{X} 4$, chloride form, and 200-400 mesh (Bio-Rad) were

\section{TABLE I}

Optimized Operating Conditions of ICP-MS

\begin{tabular}{|c|c|}
\hline ICP-MS Parameters & Values \\
\hline RF power & $1200 \mathrm{~W}$ \\
\hline Frequency & $27.2 \mathrm{MHz}$ \\
\hline $\begin{array}{l}\text { Plasma gas } \\
\text { flow rate }\end{array}$ & $11.0 \mathrm{~L} \mathrm{~min}^{-1}$ \\
\hline $\begin{array}{l}\text { Auxiliary gas } \\
\text { flow rate }\end{array}$ & $0.60 \mathrm{~L} \mathrm{~min}^{-1}$ \\
\hline $\begin{array}{l}\text { Nebulizer gas } \\
\text { flow rate }\end{array}$ & $0.75 \mathrm{~L} \mathrm{~min}^{-1}$ \\
\hline $\begin{array}{l}\text { Sample uptake } \\
\text { rate }\end{array}$ & $0.5 \mathrm{~mL} \mathrm{~min}^{-1}$ \\
\hline Measurement mode & $\begin{array}{r}\text { Dual (PC/ } \\
\text { analog) }\end{array}$ \\
\hline Acquisition time & $5 \mathrm{~s}$ \\
\hline
\end{tabular}

used for the ion exchange separation studies. Suprapur ${ }^{\circledR} \mathrm{HNO}_{3}$ and $\mathrm{HCl}$ (Merck) were used for sample preparation. De-ionized water having a resistivity of $18 \mathrm{M} \Omega{ }^{\circ} \mathrm{cm}$ (Milli$\mathrm{Q}^{\circledR}$ system, Millipore Corporation) was used for dilution. The ICP standards of $1000 \mathrm{mg} \mathrm{L}^{-1}(\mathrm{BDH})$ were diluted appropriately to prepare multi-element standard solutions. Eppendorf $^{\circledR}$ micropipettes, Nalgene ${ }^{\circledR}$ PP measuring flasks and funnels, and Teflon ${ }^{\circledR}$ PFA beakers were used throughout the experiments.

\section{Preparation of Anion Exchange Column}

Approximately $2.0 \mathrm{~g}$ resin, AG 1X4 (capacity $1.2 \mathrm{meq} / \mathrm{ml}$ resin bed), was mixed with de-ionized water to make a slurry. It was filled into the column $(4.0 \mathrm{~cm}$ o.d., 3.9 $\mathrm{cm}$ i.d., and $20.0 \mathrm{~cm}$ high) to give a resin height of approximately 10 $\mathrm{cm}$. To ensure a uniform resin bed, about $15 \mathrm{~mL}$ of water was placed in the column, the resin was drawn from the column into the weightburette and then released. The resin was allowed to settle in the column. This helped to remove any air bubbles formed when loading the column, and allowed the resin beads to settle uniformly in the column. The resin bed was conditioned by adding $30 \mathrm{~mL} 4 \mathrm{M} \mathrm{HCl}$. Glass wool was placed at the top of the resin bed to prevent the resin from being disturbed during the addition of the reagents. The average flow rate measured was $1.0 \mathrm{~mL} / \mathrm{min}$.

\section{Preparation of Synthetic Samples}

Due to the non-availability of certified reference material (CRM), synthetic samples, having 90\% of uranium and $10 \%$ of molybdenum in solution form, were prepared after dissolving high purity uranium and molybdenum metal.

\section{Dissolution of U-Mo Alloy}

Dissolution of U-Mo alloy in concentrated $\mathrm{HCl}$ takes a long time; therefore, a few drops of $\mathrm{H}_{2} \mathrm{O}_{2}$ were added. The solution was repeatedly evaporated to near dryness with the addition of $4 \mathrm{M} \mathrm{HCl}$, and finally made up to volume in a 25-mL class A volumetric flask using $4 \mathrm{M} \mathrm{HCl}$.

\section{Column Studies}

The samples were passed through the anion exchange column preconditioned with $4 \mathrm{M} \mathrm{HCl}$. Three bed volumes of $4 \mathrm{M} \mathrm{HCl}$ were passed through the column to ensure attainment of equilibrium. The collected solution was evaporated and dissolved in $1 \% \mathrm{HNO}_{3}$ for the estimation of un-retained elements using ICP-MS. The column was re-generated using $1 \mathrm{M} \mathrm{HNO}_{3}$ and $4 \mathrm{M} \mathrm{HCl}$ before loading a new sample.

\section{RESULTS AND DISCUSSION}

\section{Retention Study of $U$ and Mo}

For the desired separation of the matrix from the trace impurities, it is important to optimize the separation procedure such that the matrix is retained completely on the column and the analytes are recovered in the eluent. It is reported that retention of $U$ and Mo on an anion exchange column increases with increasing $\mathrm{HCl}$ concentration, and the conditions are optimum at $9 \mathrm{M}$ $\mathrm{HCl}$ (for $\mathrm{U}$ ) and $4 \mathrm{M} \mathrm{HCl}$ (for $\mathrm{Mo}$ ). On the other hand, some of the analytes of interest may also form anionic complexes with chloride at higher concentrations of $\mathrm{HCl}$. In view of this, $4 \mathrm{M} \mathrm{HCl}$ was chosen for the anion exchange column separation experiments.

Initially, column studies were carried out to understand the capacity of the column for dissolved U and Mo separately. The U or Mo sample was loaded onto the column, and their presence in 
the eluent was observed using the reported spectrophotometric method for U (39) and ICP-MS for Mo. The experiments were repeated by gradually increasing the loaded sample mass. It was observed that up to $125 \mathrm{mg}$ of $\mathrm{U}$ and $120 \mathrm{mg}$ of Mo could be loaded onto the column separately without detec- ting their presence in the eluent.

A similar experiment was performed using a synthetic U-Mo sample. The experiment showed up to $120 \mathrm{mg}$ loading of the sample with the concentration of $\mathrm{U}$ and $\mathrm{Mo}$ in the eluent being below the detection limit of the methods used However, on loading of additional $10 \mathrm{mg}(\mathrm{U}+\mathrm{Mo})$ sample, traces of $\mathrm{U}$ were found in the eluent. These observations helped in optimizing the maximum sample loading ( $120 \mathrm{mg}$ ) possible during the actual matrix separation experiments.

\section{Retention of Analytes}

With the optimized conditions required for complete retention of the matrix, experiments were carried out to determine the recovery of 52 different analytes. The column was loaded with a standard solution containing different elements (200 ppb each). The recoveries of the different elements studied are listed in Table II.

The column experiment was further repeated with a standard solution containing analytes (200 ppb each) and U-Mo (equivalent to alloy concentrations of $1 \mathrm{mg} / \mathrm{mL}$ ). This time the recovery was checked by performing the standard addition method. In addition to a recovery study, the standard addition method also helped in validating the method. Table III shows that 33 elements (Al, As, Ce, Cr, Co, Cs, $\mathrm{Cu}, \mathrm{Dy}, \mathrm{Eu}, \mathrm{Er}, \mathrm{Gd}$, Hf, Ho, La, Lu, $\mathrm{Mg}, \mathrm{Mn}, \mathrm{Nd}, \mathrm{Ni}, \mathrm{Pb}, \mathrm{Pr}, \mathrm{Rb}, \mathrm{Rh}, \mathrm{Sc}$, $\mathrm{Sm}, \mathrm{Sr}, \mathrm{Tb}, \mathrm{Tm}, \mathrm{V}, \mathrm{W}, \mathrm{Y}, \mathrm{Yb}$, and $\mathrm{Zr}$ ) were quantitively separated from the matrix, whereas 19 elements (Ag, Au, Ba, Bi, Cd, Fe, Ga, Ge, Hg, Ir, Nb, Os, Pd, Pt, Re, Ru, Sb, Se, Sn, $\mathrm{Ta}$, and $\mathrm{Zn}$ ) were retained significantly on the column. The precision indicated in the table is the overall precision obtained by propagation of errors and taking into account both the external $(\mathrm{N}=3)$ as well as the internal $(\mathrm{N}=10)$ standard deviation.

\section{Study of Isobaric Interferences}

The instrument was optimized on a daily basis, and the stability of the plasma was studied after a 2-hour ignition of the plasma. Spectroscopic interferences due to isobaric atomic or polyatomic ions were corrected according to the reports $(40,41)$. Considering the low concentration of REEs (present in the sub-ppm range) and no detectable $\mathrm{Ba}$ in the U-Mo alloy, the individual analyte intensities were only considered without applying any polyatomic interference correction.

\section{Detection Limit}

Both the instrument detection limits (IDLs) and the method detection limits (MDLs) were determined for the analytes of interest as per

\section{TABLE II}

Retention Studies of 52 Elements (each at 200 ppb) in the Absence of the Matrix

\begin{tabular}{ll}
\hline Recovery (\%) & \multicolumn{1}{c}{ Analytes (each having $200 \mathrm{ppb}$ ) } \\
\hline 90-100 & $\mathrm{Ba}, \mathrm{Ce}, \mathrm{Cr}, \mathrm{Co}, \mathrm{Cs}, \mathrm{Cu}, \mathrm{Dy}, \mathrm{Eu}, \mathrm{Er}, \mathrm{Gd}, \mathrm{Hf}, \mathrm{Ho}, \mathrm{La}, \mathrm{Lu}, \mathrm{Mn}$, \\
& $\mathrm{Mg}, \mathrm{Nd}, \mathrm{Ni}, \mathrm{Pr}, \mathrm{Rb}, \mathrm{Sc}, \mathrm{Sm}, \mathrm{Sr}, \mathrm{Tb}, \mathrm{Tm}, \mathrm{V}, \mathrm{W}, \mathrm{Yb}, \mathrm{Zr}$ \\
$75-90$ & $\mathrm{Al}, \mathrm{As}, \mathrm{Ir} \mathrm{Pb}, \mathrm{Rh}, \mathrm{Y}$ \\
$25-50$ & $\mathrm{Nb}, \mathrm{Se}, \mathrm{Zn}$ \\
$<10$ & $\mathrm{Ag}, \mathrm{Au}, \mathrm{Bi}, \mathrm{Cd}, \mathrm{Fe}, \mathrm{Ga}, \mathrm{Ge}, \mathrm{Hg}, \mathrm{Os}, \mathrm{Pd}, \mathrm{Pt}, \mathrm{Re}, \mathrm{Ru}, \mathrm{Sb}, \mathrm{Sn}, \mathrm{Ta}, \mathrm{Ti}$ \\
\hline
\end{tabular}

\section{Atomic Apectroscopy $\bigcirc$ Vol. 38(5), Sept./Oct. 2017}

reported procedure (42). The IDLs were obtained by analyzing the elements in $1 \%(\mathrm{v} / \mathrm{v})$ pure $\mathrm{HNO}_{3}$ solution for all of these elements. For MDL determination, the separation procedure as discussed was followed exactly in the absence of the sample, and the solutions were analyzed by ICP-MS. The $3 \sigma$ values of the IDLs and MDLs are tabulated in Table IV.

\section{Analysis of Real Samples}

Analysis of real samples of different lots was carried out following the methodology described above. The flow diagram for the final optimized procedure is given in Figure 1 and the results are listed in the Table V. As is evident from this table, the concentrations of the trace metallic impurities are well below the specification limits for ASTM (American Standards for Testing Materials) nuclear grade uranium metal. The fabrication procedure for the U-Mo alloy is being developed (6). The trace metallic impurity concentrations determined in different lots by this method will help in understanding the lowest possible impurities during the fabrication. This in turn will help in deciding the specification limits of trace metallic impurities for the alloy.

\begin{tabular}{c}
\hline Preweighted U-Mo \\
alloy samples \\
$\downarrow$ \\
Dissolve in conc $\mathrm{HCl}$ \\
and few drops $\mathrm{H}_{2} \mathrm{O}_{2}$ \\
and finally in $4 \mathrm{M} \mathrm{HCl}$ \\
$\downarrow$ \\
Column separation \\
(Matrix Separation) \\
$\downarrow$ \\
Analytes collection \\
and analysis by ICP-MS \\
\hline
\end{tabular}

Fig. 1. Systematic diagram for the analysis of U-Mo alloy. 
TABLE III

Recovery of Trace Elements in Synthetic U-Mo Sample (Sample Amount $=0.1 \mathrm{~g}$, Volume $=25 \mathrm{~mL}, \mathbf{N}=10$ )

\begin{tabular}{|c|c|c|c|c|c|c|c|c|c|}
\hline $\begin{array}{l}\text { Sr. } \\
\text { No. }\end{array}$ & $\begin{array}{l}\text { Ele- } \\
\text { ment }\end{array}$ & $\begin{array}{l}\text { Added } \\
(\mu g)\end{array}$ & $\begin{array}{l}\text { Found } \\
(\mu g)\end{array}$ & $\begin{array}{c}\text { Recovery } \\
(\%)\end{array}$ & $\begin{array}{l}\text { Sr. } \\
\text { No. }\end{array}$ & $\begin{array}{c}\text { Ele- } \\
\text { ment }\end{array}$ & $\begin{array}{c}\text { Added } \\
(\mu g)\end{array}$ & $\begin{array}{l}\text { Found } \\
\text { ( } \mu \mathrm{g})\end{array}$ & $\begin{array}{c}\text { Recovery } \\
(\%)\end{array}$ \\
\hline \multirow[t]{4}{*}{1} & \multirow[t]{4}{*}{$\mathrm{Al}$} & 0 & $17.53 \pm 1.41$ & - & \multirow[t]{4}{*}{11} & \multirow[t]{4}{*}{ Gd } & 0 & $0.23 \pm 0.01$ & - \\
\hline & & 5 & $21.83 \pm 1.97$ & $86.0 \pm 10.4$ & & & 5 & $4.30 \pm 0.21$ & $81.4 \pm 5.3$ \\
\hline & & 10 & $26.52 \pm 2.52$ & $89.9 \pm 11.2$ & & & 10 & $8.82 \pm 0.51$ & $85.9 \pm 6.2$ \\
\hline & & 15 & $31.42 \pm 3.10$ & $92.6 \pm 11.8$ & & & 15 & $13.96 \pm 0.85$ & $91.5 \pm 6.8$ \\
\hline \multirow[t]{4}{*}{2} & \multirow[t]{4}{*}{ As } & 0 & $2.85 \pm 0.15$ & - & \multirow[t]{4}{*}{12} & \multirow[t]{4}{*}{ Hf } & 0 & $0.23 \pm 0.01$ & - \\
\hline & & 5 & $7.15 \pm 0.21$ & $86.0 \pm 5.2$ & & & 5 & $4.54 \pm 0.22$ & $86.1 \pm 5.6$ \\
\hline & & 10 & $12.06 \pm 0.45$ & $92.1 \pm 5.9$ & & & 10 & $9.20 \pm 0.58$ & $89.7 \pm 6.9$ \\
\hline & & 15 & $17.25 \pm 0.69$ & $96.0 \pm 6.3$ & & & 15 & $14.00 \pm 0.91$ & $91.8 \pm 7.2$ \\
\hline \multirow[t]{4}{*}{3} & \multirow[t]{4}{*}{$\mathrm{Ce}$} & 0 & $0.27 \pm 0.01$ & - & \multirow[t]{4}{*}{13} & \multirow[t]{4}{*}{ Ho } & 0 & $0.33 \pm 0.04$ & - \\
\hline & & 5 & $4.15 \pm 0.08$ & $77.6 \pm 3.2$ & & & 5 & $4.21 \pm 0.19$ & $77.5 \pm 10.0$ \\
\hline & & 10 & $8.43 \pm 0.13$ & $81.6 \pm 3.3$ & & & 10 & $8.31 \pm 0.52$ & $79.8 \pm 10.9$ \\
\hline & & 15 & $13.08 \pm 1.01$ & $85.4 \pm 7.3$ & & & 15 & $12.62 \pm 1.01$ & $81.9 \pm 11.9$ \\
\hline \multirow[t]{4}{*}{4} & \multirow[t]{4}{*}{$\mathrm{Cr}$} & 0 & $2.86 \pm 0.10$ & - & \multirow[t]{4}{*}{14} & \multirow[t]{4}{*}{$\mathrm{La}$} & 0 & $0.25 \pm 0.01$ & - \\
\hline & & 5 & $6.87 \pm 0.15$ & $80.2 \pm 3.3$ & & & 5 & $4.11 \pm 0.22$ & $77.2 \pm 7.4$ \\
\hline & & 10 & $11.43 \pm 0.27$ & $85.7 \pm 3.6$ & & & 10 & $8.23 \pm 0.51$ & $79.8 \pm 8.1$ \\
\hline & & 15 & $16.24 \pm 1.12$ & $89.2 \pm 6.9$ & & & 15 & $12.66 \pm 0.95$ & $82.7 \pm 9.1$ \\
\hline \multirow[t]{5}{*}{5} & \multirow[t]{5}{*}{ Co } & 0 & $0.39 \pm 0.02$ & - & \multirow[t]{4}{*}{15} & \multirow[t]{4}{*}{$\mathrm{Lu}$} & 0 & $0.24 \pm 0.01$ & - \\
\hline & & 5 & $4.38 \pm 0.09$ & $79.8 \pm 4.4$ & & & 5 & $4.54 \pm 0.25$ & $85.9 \pm 5.9$ \\
\hline & & & & & & & 10 & $9.02 \pm 0.55$ & $87.8 \pm 6.5$ \\
\hline & & 10 & $8.74 \pm 0.25$ & $83.5 \pm 4.9$ & & & 15 & $14.01 \pm 0.88$ & $91.8 \pm 6.9$ \\
\hline & & 15 & $13.31 \pm 1.05$ & $86.1 \pm 8.1$ & \multirow[t]{4}{*}{16} & $\mathrm{Mg}$ & 0 & $2.85 \pm 0.15$ & - \\
\hline \multirow[t]{4}{*}{6} & \multirow[t]{4}{*}{ Cs } & 0 & $0.28 \pm 0.01$ & - & & & 5 & $7.53 \pm 0.29$ & $93.6 \pm 6.1$ \\
\hline & & 5 & $4.11 \pm 0.06$ & $76.5 \pm 3.0$ & & & 10 & $12.30 \pm 0.57$ & $94.5 \pm 6.6$ \\
\hline & & 10 & $8.45 \pm 0.23$ & $81.7 \pm 3.7$ & & & 15 & $17.41 \pm 1.15$ & $97.1 \pm 8.2$ \\
\hline & & 15 & $13.03 \pm 1.10$ & $85.2 \pm 7.8$ & 17 & Mn & 0 & $4.27 \pm 0.32$ & - \\
\hline 7 & $\mathrm{Cu}$ & 0 & $6.33 \pm 0.23$ & - & & & 5 & $9.24 \pm 0.65$ & $99.4 \pm 10.2$ \\
\hline & & 5 & $11.15 \pm 0.38$ & $96.4 \pm 4.8$ & & & 10 & $13.98 \pm 0.61$ & $97.1 \pm 8.4$ \\
\hline & & 10 & $16.08 \pm 0.45$ & $97.5 \pm 4.5$ & & & 15 & $19.22 \pm 1.21$ & $99.7 \pm 9.8$ \\
\hline & & 15 & $21.23 \pm 1.21$ & $99.3 \pm 6.7$ & 18 & $\mathrm{Nd}$ & 0 & $0.22 \pm 0.01$ & - \\
\hline 8 & Dy & 0 & $0.27 \pm 0.01$ & - & & & 5 & $4.20 \pm 0.28$ & $79.6 \pm 6.4$ \\
\hline & & 5 & $4.62 \pm 0.10$ & $86.9 \pm 3.7$ & & & 10 & $8.57 \pm 0.53$ & $83.5 \pm 6.4$ \\
\hline & & 10 & $9.45 \pm 0.25$ & $91.8 \pm 4.1$ & & & 15 & $13.11 \pm 1.09$ & $85.9 \pm 8.1$ \\
\hline & & 15 & $14.30 \pm 1.05$ & $93.5 \pm 7.7$ & 19 & $\mathrm{Ni}$ & 0 & $10.24 \pm 0.49$ & - \\
\hline 9 & $\mathrm{Eu}$ & 0 & $0.22 \pm 0.01$ & - & & & 5 & $14.46 \pm 0.82$ & $84.4 \pm 6.3$ \\
\hline & & 5 & $4.35 \pm 0.10$ & $82.6 \pm 4.2$ & & & 10 & $19.36 \pm 1.01$ & $91.2 \pm 6.5$ \\
\hline & & 10 & $8.79 \pm 0.18$ & $85.7 \pm 4.3$ & & & 15 & $24.65 \pm 1.58$ & $96.1 \pm 7.7$ \\
\hline & & 15 & $13.59 \pm 1.12$ & $89.1 \pm 8.4$ & 20 & $\mathrm{~Pb}$ & 0 & $0.62 \pm 0.06$ & - \\
\hline 10 & $\mathrm{Er}$ & 0 & $0.36 \pm 0.03$ & - & & & 5 & $4.38 \pm 0.35$ & $75.2 \pm 9.4$ \\
\hline & & 5 & $4.22 \pm 0.26$ & $80.0 \pm 8.3$ & & & 10 & $8.26 \pm 0.74$ & $76.4 \pm 10.1$ \\
\hline & & 10 & $8.71 \pm 0.52$ & $84.9 \pm 8.7$ & & & 15 & $12.14 \pm 1.33$ & $76.8 \pm 11.2$ \\
\hline & & 15 & $13.65 \pm 1.0$ & $89.5 \pm 9.91$ & & & & $12.14 \pm 1.55$ & $70.0 \pm 11.2$ \\
\hline
\end{tabular}




\section{A Amic}

TABLE III (cont'd)

Recovery of Trace Elements in Synthetic U-Mo Sample (Sample Amount $=0.1 \mathrm{~g}$, Volume $=25 \mathrm{~mL}, \mathbf{N}=10$ )

\begin{tabular}{|c|c|c|c|c|c|c|c|c|c|c|}
\hline $\begin{array}{l}\text { Sr. } \\
\text { No. }\end{array}$ & $\begin{array}{l}\text { Ele- } \\
\text { ment }\end{array}$ & $\begin{array}{l}\text { Added } \\
(\mu \mathrm{g})\end{array}$ & $\begin{array}{l}\text { Found } \\
(\mu \mathrm{g})\end{array}$ & $\begin{array}{l}\text { Recovery } \\
(\%)\end{array}$ & $\begin{array}{cc}\text { Sr. } & \text { Ele } \\
\text { No. } & \text { me }\end{array}$ & $\begin{array}{l}\text { Ele- } \\
\text { ment }\end{array}$ & $\begin{array}{l}\text { Added } \\
(\mu \mathrm{g})\end{array}$ & $\begin{array}{c}\text { Found } \\
(\mu \mathrm{g})\end{array}$ & \multicolumn{2}{|c|}{$\begin{array}{c}\text { Recovery } \\
(\%)\end{array}$} \\
\hline \multirow[t]{4}{*}{21} & $\operatorname{Pr}$ & 0 & $0.24 \pm 0.01$ & - & \multirow[t]{4}{*}{31} & \multirow[t]{3}{*}{$\mathrm{Y}$} & 0 & $0.38 \pm 0.04$ & \multicolumn{2}{|l|}{ - } \\
\hline & & 5 & $4.23 \pm 0.25$ & $79.8 \pm 5.8$ & & & 5 & $4.20 \pm 0.27$ & \multicolumn{2}{|c|}{$76.4 \pm 9.4$} \\
\hline & & 10 & $8.67 \pm 0.58$ & $84.3 \pm 6.6$ & & & & $8.19 \pm 0.59$ & \multicolumn{2}{|c|}{$78.1 \pm 10.0$} \\
\hline & & 15 & $13.25 \pm 0.79$ & $86.7 \pm 6.3$ & & 1 & & $12.41 \pm 1.17$ & \multicolumn{2}{|c|}{$80.2 \pm 11.3$} \\
\hline \multirow[t]{4}{*}{22} & $\mathrm{Rb}$ & 0 & $0.30 \pm 0.02$ & - & \multirow[t]{4}{*}{32} & \multirow[t]{2}{*}{$\mathrm{Yb}$} & 0 & $0.22 \pm 0.03$ & \multicolumn{2}{|c|}{-} \\
\hline & & 5 & $4.05 \pm 0.27$ & $75.0 \pm 7.1$ & & & 4.3 & $4 \pm 0.28$ & 82.4 & \pm \pm 12.4 \\
\hline & & 10 & $8.05 \pm 0.65$ & $77.5 \pm 8.1$ & & 1 & 9.0 & $1 \pm 0.53$ & 87.9 & \pm 13.1 \\
\hline & & 15 & $12.32 \pm 1.11$ & $80.1 \pm 9.0$ & & 1 & 13. & $95 \pm 1.19$ & 91.5 & \pm 14.7 \\
\hline 23 & $\mathrm{Rh}$ & 0 & $0.28 \pm 0.03$ & - & 33 & 0 & 5.6 & $3 \pm 0.29$ & - & \\
\hline & & 5 & $4.13 \pm 0.30$ & $77.0 \pm 9.9$ & & 5 & 9.4 & $3 \pm 0.71$ & 76.0 & \pm 6.9 \\
\hline & & 10 & $8.06 \pm 0.71$ & $77.8 \pm 10.8$ & & 1 & 13. & $36 \pm 1.05$ & 77.3 & \pm 7.3 \\
\hline & & 15 & $12.21 \pm 1.31$ & $79.5 \pm 12.1$ & & 1 & 17. & $62 \pm 1.65$ & 79.9 & \pm 8.9 \\
\hline 24 & Sc & 0 & $0.32 \pm 0.03$ & - & & & & & & \\
\hline & & 5 & $4.15 \pm 0.35$ & $76.6 \pm 9.7$ & & & & & & \\
\hline & & 10 & $9.35 \pm 0.86$ & $90.3 \pm 11.9$ & & & & BLE IV & & \\
\hline & & 15 & $14.19 \pm 1.21$ & $92.5 \pm 11.7$ & Instr & rument & Detection & Limit ( & (IDL) and & 1 Method \\
\hline 25 & $\mathrm{Sm}$ & 0 & $0.22 \pm 0.01$ & - & Dete & ction $\mathrm{Li}$ & mit (MDI & for $\mathrm{Al}$ & 1 Analyte & s $(\mathrm{N}=10)$ \\
\hline & & 5 & $4.35 \pm 0.28$ & $82.6 \pm 6.5$ & Ele- & IDL & MDL & Ele- & IDL & MDL \\
\hline & & 10 & $9.65 \pm 0.63$ & $94.3 \pm 5.1$ & ments & $\left(\mathrm{ng} \mathrm{L}^{-1}\right)$ & $\left(\mu \mathrm{g} \mathrm{Kg}^{-1}\right)$ & ments & $\left(\right.$ ng L L $\left.^{-1}\right)$ & $\left.\mu \mathrm{g} \mathrm{Kg}^{-1}\right)$ \\
\hline & & 15 & $14.81 \pm 1.18$ & $97.3 \pm 8.9$ & $\mathrm{Al}$ & 200 & 10 & $\mathrm{Nd}$ & 10 & 1 \\
\hline 26 & $\mathrm{Sr}$ & 0 & $0.34 \pm 0.03$ & - & As & 150 & 15 & $\mathrm{Ni}$ & 80 & 3 \\
\hline & & 5 & $4.12 \pm 0.29$ & $75.6 \pm 8.5$ & $\mathrm{Ce}$ & 15 & 1 & $\mathrm{~Pb}$ & 30 & 4 \\
\hline & & 10 & $7.94 \pm 0.65$ & $76.0 \pm 9.1$ & $\mathrm{Cr}$ & 100 & 1 & $\operatorname{Pr}$ & 10 & 1 \\
\hline & & 15 & $11.95 \pm 1.18$ & $77.4 \pm 10.2$ & Co & 20 & 6 & $\mathrm{Rb}$ & 50 & 2 \\
\hline 27 & $\mathrm{~Tb}$ & 0 & $0.24 \pm 0.02$ & - & Cs & 120 & 5 & $\mathrm{Rh}$ & 50 & 5 \\
\hline & & 5 & $4.96 \pm 0.33$ & $94.4 \pm 10.1$ & $\mathrm{Cu}$ & 150 & 7 & Sc & 25 & 5 \\
\hline & & 10 & $10.10 \pm 0.61$ & $98.6 \pm 10.2$ & Dy & 5 & 1 & Sm & 7 & 1 \\
\hline & & 15 & $14.95 \pm 1.11$ & $98.1 \pm 10.9$ & $\mathrm{Eu}$ & 10 & 1 & $\mathrm{Sr}$, & 50 & 10 \\
\hline 28 & $\mathrm{Tm}$ & 0 & $0.24 \pm 0.02$ & - & Er & 20 & 1 & $\mathrm{~Tb}$ & 10 & 1 \\
\hline & & 5 & $4.65 \pm 0.26$ & $88.2 \pm 8.9$ & Gd & 10 & 1 & $\mathrm{Tm}$ & 20 & 1 \\
\hline & & 10 & $9.61 \pm 0.59$ & $93.7 \pm 9.7$ & $\mathrm{Hf}$ & 30 & 1 & V & 25 & 2 \\
\hline & & 15 & $14.15 \pm 1.18$ & $92.7 \pm 10.6$ & Ho & 25 & 1 & W & 100 & 5 \\
\hline 29 & V & 0 & $0.49 \pm 0.03$ & - & $\mathrm{La}$ & 10 & 2 & $\mathrm{Y}$ & 50 & 5 \\
\hline & & 5 & $4.25 \pm 0.25$ & $75.2 \pm 6.4$ & $\mathrm{Lu}$ & 15 & 2 & $\mathrm{Yb}$ & 25 & 2 \\
\hline & & 10 & $8.11 \pm 0.62$ & $76.2 \pm 7.5$ & $\mathrm{Mg}$ & 75 & 10 & $\mathrm{Zr}$ & 100 & 10 \\
\hline & & 15 & $12.24 \pm 1.21$ & $78.3 \pm 10.8$ & $\mathrm{Mn}$ & 30 & 2 & & & \\
\hline
\end{tabular}

.Note: MDL calculated in absence of originl sample. 
TABLE V

Trace Element Concentrations in the U-Mo Samples of Different Lots (in $\mu \mathrm{g} / \mathrm{g}$ )

\begin{tabular}{|c|c|c|c|}
\hline Elements & Sample I & Sample II & Sample III \\
\hline $\mathrm{Al}$ & $220.6 \pm 19.5$ & $159.4 \pm 7.8$ & $183.5 \pm 9.5$ \\
\hline As & $9.9 \pm 1.2$ & $15.3 \pm 0.9$ & $1.5 \pm 0.2$ \\
\hline $\mathrm{Ce}$ & $2.6 \pm 0.16$ & $0.20 \pm 0.01$ & $<\mathrm{BDL}$ \\
\hline $\mathrm{Cr}$ & $28.8 \pm 2.3$ & $36.3 \pm 1.6$ & $23.8 \pm 0.6$ \\
\hline Co & $3.9 \pm 0.3$ & $<\mathrm{BDL}$ & $<\mathrm{BDL}$ \\
\hline Cs & $2.8 \pm 0.2$ & $<\mathrm{BDL}$ & $<\mathrm{BDL}$ \\
\hline $\mathrm{Cu}$ & $63.7 \pm 5.1$ & $62.3 \pm 3.1$ & $49.6 \pm 1.3$ \\
\hline Dy & $2.2 \pm 0.2$ & $0.3 \pm 0.02$ & $0.06 \pm 0.01$ \\
\hline $\mathrm{Eu}$ & $2.3 \pm 0.2$ & $<\mathrm{BDL}$ & $<\mathrm{BDL}$ \\
\hline $\mathrm{Er}$ & $3.7 \pm 0.3$ & $<\mathrm{BDL}$ & $1.0 \pm 0.11$ \\
\hline Gd & $2.4 \pm 0.2$ & $<\mathrm{BDL}$ & $<\mathrm{BDL}$ \\
\hline $\mathrm{Hf}$ & $2.3 \pm 0.2$ & $7.4 \pm 0.3$ & $0.10 \pm 0.01$ \\
\hline Ho & $3.4 \pm 0.3$ & $0.2 \pm 0.05$ & $1.5 \pm 0.33$ \\
\hline $\mathrm{La}$ & $2.5 \pm 0.2$ & $0.2 \pm 0.02$ & $<\mathrm{BDL}$ \\
\hline $\mathrm{Mg}$ & $28.7 \pm 1.7$ & $18.6 \pm 1.0$ & $13.8 \pm 0.6$ \\
\hline $\mathrm{Mn}$ & $42.9 \pm 3.0$ & $59.9 \pm 6.5$ & $56.3 \pm 4.5$ \\
\hline $\mathrm{Nd}$ & $2.2 \pm 0.2$ & $<\mathrm{BDL}$ & $<\mathrm{BDL}$ \\
\hline $\mathrm{Ni}$ & $103.2 \pm 6.2$ & $73.5 \pm 3.1$ & $98.5 \pm 5.6$ \\
\hline $\mathrm{Pb}$ & $83.8 \pm 7.4$ & $7.5 \pm 0.3$ & $3.2 \pm 0.3$ \\
\hline $\operatorname{Pr}$ & $2.4 \pm 0.2$ & $<\mathrm{BDL}$ & $<\mathrm{BDL}$ \\
\hline $\mathrm{Rb}$ & $3.0 \pm 0.2$ & $<\mathrm{BDL}$ & $<\mathrm{BDL}$ \\
\hline $\mathrm{Rh}$ & $2.7 \pm 0.2$ & $<\mathrm{BDL}$ & $<\mathrm{BDL}$ \\
\hline $\mathrm{Sc}$ & $3.2 \pm 0.2$ & $1.8 \pm 0.1$ & $1.4 \pm 0.1$ \\
\hline $\mathrm{Sm}$ & $2.2 \pm 0.2$ & $<\mathrm{BDL}$ & $<\mathrm{BDL}$ \\
\hline $\mathrm{Sr}$ & $3.2 \pm 0.3$ & $0.7 \pm 0.05$ & $<\mathrm{BDL}$ \\
\hline $\mathrm{Tb}$ & $2.4 \pm 0.2$ & $0.06 \pm 0.01$ & $<\mathrm{BDL}$ \\
\hline $\mathrm{Tm}$ & $2.4 \pm 0.2$ & $<0.01$ & $<0.01$ \\
\hline V & $7.1 \pm 0.6$ & $69.2 \pm 3.6$ & $0.6 \pm 0.04$ \\
\hline W & $75.5 \pm 6.9$ & $57.5 \pm 2.8$ & $49.5 \pm 2.9$ \\
\hline Y & $3.8 \pm 0.3$ & $1.7 \pm 0.06$ & $0.1 \pm 0.01$ \\
\hline $\mathrm{Yb}$ & $2.2 \pm 0.2$ & $<\mathrm{BDL}$ & $<\mathrm{BDL}$ \\
\hline $\mathrm{Zr}$ & $70.8 \pm 6.8$ & $299.5 \pm 15.4$ & $6.1 \pm 0.5$ \\
\hline
\end{tabular}

BDL: Below Detection Limit of MDL.

\section{CONCLUSION}

Anion exchange separation was used for the simultaneous separation of $\mathrm{U}$ and Mo from the analytes. It was possible to recover 33 analytes (Al, As, Ce, Cr, Co, Cs, Cu, Dy, $\mathrm{Eu}, \mathrm{Er}, \mathrm{Gd}, \mathrm{Hf}, \mathrm{Ho}, \mathrm{La}, \mathrm{Lu}, \mathrm{Mg}, \mathrm{Mn}$, $\mathrm{Nd}, \mathrm{Ni}, \mathrm{Pb}, \mathrm{Pr}, \mathrm{Rb}, \mathrm{Rh}, \mathrm{Sc}, \mathrm{Sm}, \mathrm{Sr}$, $\mathrm{Tb}, \mathrm{Tm}, \mathrm{V}, \mathrm{W}, \mathrm{Y}, \mathrm{Yb}$, and $\mathrm{Zr}$ ) from the sample with a recovery of more than $75 \%$. The separation procedure is simple and can be employed for routine analysis of U-Mo samples. The generation of organic and radioactive liquid waste is reduced significantly. The method was successfully employed for the analysis of trace impurities in several real samples.

Received September 26, 2016.

\section{REFERENCES}

1. S.V.D. Berghe and P. Lemoine, Nucl. Engineering and Technology 46(2), 125 (2014).

2. V.P. Sinha, P.V. Hegde, G.J. Prasad, G.P. Mishra, and S. Pal, Trans. Indian Inst.Met. 61(2-3), 115 (2008)/

3. Y.I. Chang, Nuclear Engineering and Technology 39(3), 161 (2007).

4. E. Perez, B. Yao, D.D. Keiser Jr., and Y-H. Sohn, J. Nucl. Mater. 402, 8 (2010).

5. Y.S. Kim and G.L. Hofman, J. Nucl. Mater. 419, 291 (2011).

6. V.P. Sinha, P.V. Hegde, G.J. Prasad, G.K. Dey, and H.S. Kamath, J. Alloy Compd. 491, 753 (2010).

7. R. Avni, Spectrochim. Acta 23B, 619 (1969).

8. ASTM C1517-16, Standard Test Method for Determination of Metallic Impurities in Uranium Metal or Compounds by DC-Arc Emission Spectroscopy.

9. A.L. de Souza, M.E.B. Cotrim, and M.A.F. Pires, Microchem. J. 106, 194 (2013).

10. www.iaea.org/inis/collection/ NCLCollectionStore/_Public/34/ 030/34030687.pdf 


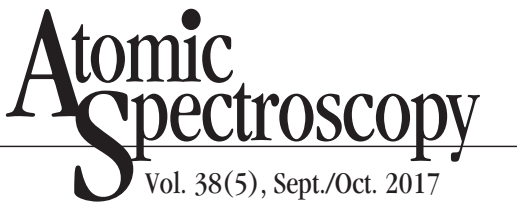

11. Z. Varga, R. Katona, Z. Stefánka, M. Wallenius, K. Mayer, and A. Nicholl, Talanta 80, 1744 (2010).

12. J. I. G. Alonso, Anal. Chem. Acta 312, 57 (1995).

13. J.M.B. Moreno, J.I.G. Alonso, P. Arbore, G. Nicolaou and L. Koch, J. Anal. At. Spectrom. 10, 929 (1996).

14. A. Pitois, L.A..de Las Heras and M. Betti, Int. J. Mass Spectrom. 270, 118 (2008).

15. R.K. Malhotra and K. Satyanarayana, Talanta 50, 601 (1999).

16. M. Betti, J. Chromatogr. A 789, 369 (1997).

17. P.C. Kruger, M.S. Bloom, J.G. Arnason, C.D.Palmer, V.Y.Fujimoto and P.J.Parsons, J. Anal. At. Spectrom. 27, 1245 (2012).

18. D. Dick, A. Wegner, P. Gabrielli, U Ruth, C.Barbate and M.Kriews, Anal. Chim. Acta 621, 140 (2008).

19. S. Tokalioğlu, Food Chem. 134, 2504 (2012).

20. J. R. Kumar, J.S. Kim, J.Y. Lee, and H.S. Yoon, Separation \& Purification Reviews 40, 77 (2011).

21. G. Jin-Xin, S. Si-Xiu, D. Dong-li, L. Ming-Xia, P. Hua, and M. Zhao- li, J. Radioanal. Nucl. Ch. 267(3), 675 (2006).

22. C. A. Horton, and J.C. White, Anal. Chem. 30(11), 1779 (1958).

23. Y. Shigetomi, T. Kojima, and H. Kamba, J. Nucl. Sci. Technol. 20(2), 140 (1983).

24. I. Haiduc, M. Curtui, and I. Haiduc, J. Radioanal. Nucl. Chem. 99(2), 257 (1986).

25. S.D. Dogmane, R.K. Singh, D.D. Bajpai, and J.N. Mathur, J. Radioanal. Nucl. Chem. 253(3), 477 (2002).

26. S.I. Ei-Dessouky, J. Radioanal. Nucl. Chem. 260(3), 613 (2004).

27. R.G. Talla, S.U. Gaikwad, and S.D. Pawar, Indian J. Chem. Techn. 17, 436 (2010).

28. S.V. Vartak and V.M. Shinde, Talanta 43, 1465 (1996).

29. A.R. Ghiasvand, S. Shadabi, E. Mohagheghzadeh, and P. Hashemi, Talanta 66, 912 (2005).
30. A. Rao, A.K Sharma, P. Kumar, M.M. Charyulu, B.S. Tomar, and K.L. Ramakumar, Appl. Radiat. Isotopes 89, 186 (2014).

31.

http://www.iaea.org/inis/collectio n/NCLCollectionStore/_Public/ 20/028/20028872.pdf

32. R. Djogic, V. Cuculic, and M. Branica, Croat. Chem. Acta 78(4), 575 (2005).

33. M.O. Sornein, C. Cannes, C.L. Naour, G. Lagarde, E. Simoni, and J.C. Berthet, Inorg. Chem. 45, 10419 (2006).

34. P.A. Barnard, I.W. Sun, and C. L. Hussey, Inorg. Chem. 29, 3670 (1990).

35. O.A. Vita, C.R. Walker, C.F. Trivisonno, and R.W. Sparks, Anal. Chem. 42(4), 465-.(1970).

36. F.Tera and J.Korkisch, Anal. Chim. Acta 25(3), 222 (1961).

37. T. H. Nguyen and M. S. Lee, Hydrometallurgy 136, 65 (2013).

38. P. N. Nomngongo, J.C. Ngila, J. N. Kamau, T.A.M. Msagati, and B. Moodley, Talanta 110, 153 (2013).

39. L. Jauberty, N. Drogat, J. L. Decossas, V. Delpech, V. Gloaguen, and V. Sol, Talanta 115, 751 (2013).

40. M.A. Vaugan and G. Horlick, Appl. Spectrosc. 40, 434 (1986).

41. M.M. Kershisnik, R. Kalamegam, K.O. Ash, D.E. Nixon, and E.R. Ashwood, Clin. Chem. 38(11), 2197 (1992).

42. A.S. Zawadka, P. Konieczka, E. Przyk, and J. Namiesnik, Anal. Lett. 38, 353 (2005). 